\title{
Lefebvre's Production of Space in the Context of Turkey: A Comprehensive Literature Survey
}

\author{
Husik Ghulyan'
}

\begin{abstract}
This article presents a comprehensive survey of applications of Henri Lefebvre's theorizations on space in the Turkish context. Through an intensive search and screening of the literature, this article "maps" relevant studies in terms of research topic, geographic and historical scope, and the conceptual framework and concepts used while presenting the general trends and patterns of applications of Lefebvrean space frameworks in the Turkish context. According to the main argument of the study, although there have been intensive applications of various Lefebvrean conceptualizations on space for the case of Turkey, in most of the relevant scholarship, the focus has been on the spatial triad framework or its various components, rather than on a systematic and comprehensive contextualization of the theory.
\end{abstract}

\section{Keywords}

Henri Lefebvre, production of space, spatial triad, Turkey, literature survey

\section{Introduction}

As Stuart Elden notes, in the 1990s, one could speak of a "renaissance of interest" in the work of Henri Lefebvre (1991), since it was in the 1990s that the English-speaking world finally had access to some of his most important works (Elden, 2001, p. 809), with The Production of Space representing Lefebvre's most important set of theorizations and conceptualizations on space. It is in this work that Lefebvre presents his theory of the production of space, and where one finds his most comprehensive and systematic discussions on space. Perhaps, the 1991 translation and publication of this work was one of the main reasons that in the Englishspeaking world, "much of the attention to Lefebvre's work has been in the field of geography, or related areas such as urban sociology or cultural studies" (Elden, 2001, p. 809), as conceptualizations presented there appear convenient and productive for these fields.

The initial propositions of The Production of Space have been expanded by a wide range of scholars (Brenner \& Elden, 2009; Elden, 2001, 2004; Elden, Lebas, \& Kofman, 2003; Erdi-Lelandais, 2014c; Goonewardena, Kipfer, Milgrom, \& Schmid, 2008; Gottdiener, 1987, 1993; Gregory, 1995; Kipfer, 2002; Kipfer, Saberi, \& Wieditz, 2013; Merrifield, 2013; Shields, 2005; Soja, 1996; Stanek, 2011; Zieleniec, 2007), thus nowadays Lefebvrean theoretical propositions and concepts on space have become the core of any scholarship pertaining to theoretical and practical aspects of space and spatializations.

With Lefebvrean production of space theory becoming popular in emergent scholarship pertaining to space and spatializations, particularly in the scholarship embarking upon employing Lefebvre's various concepts into particular cases, one can find all kind of interesting explications and contextualizations of respective notions, like the notion of abstract space or representational space, contextualizations, which frequently detach the respective notions from the structure and context of the larger theory, and contextualize with respect to research in geography or urban sociology, yet without much consideration given to Lefebvre's critique to such an approach: approach producing either "mere descriptions which never achieve analytical, much less theoretical, status, or else fragments and cross-sections of space" (Lefebvre, 1991, p. 7). Indeed, the dominance of that approach was one of Lefebvre's departure points for embarking upon his "unitary theory" of space. As a result, year by year, one sees a growing body of literature, especially case

\footnotetext{
'Ankara University, Turkey

Corresponding Author:

Husik Ghulyan, Graduate School of Social Sciences, Ankara University, Emniyet, Dogöl Cad. 6A, 06560, Yenimahalle, Ankara, Turkey. Email: husikghulyan@gmail.com
} 
studies, which try to apply various concepts elaborated by Lefebvre, in different geographical and historical contexts.

In The Production of Space (1991), Lefebvre's production of space theory is composed of two main structurally interrelated frameworks: the first refers to the periodization of space framework and consists of absolute space, sacred space, historical space, abstract space, contradictory space, and differential space; the second refers to the spatial triad framework and consists of spatial practices (perceived space), representations of space (conceived space), and representational space (lived space).

The Lefebvrean periodization of space framework although is considered by some as "stereotypical, linear, Eurocentric modelling of historical progress" (Shields, 2005 , p. 170), notwithstanding, the framework appears as Lefebvre's one of the most unique contributions to the general theory of space and the only available coherent framework to understand "the long history of space," which according to Lefebvre should "be distinguished from an inventory of things in space (or what has recently been called material culture or civilization), as also from ideas and discourse about space" (Lefebvre, 1991, p. 116), the inventory of things in space appearing as the space of history. Moreover, according to Lefebvre (1991), the history of space must deal with "modes of production as generalities covering specific societies with their particular histories and institutions" (p. 48). Thus, in this respect, one sees a coherence between Lefebvrean periodization of space framework and the general history of modes of production in Marxism or as Boer (2015) points, The Production of Space "seeks to refashion Marxist periodization in terms of space" (p. 95). ${ }^{1}$ As a result, in the Lefebvrean periodization of space framework, absolute space corresponds to tribal (hunting and gathering) societies and Neolithic agriculture, sacred space pertains to Asiatic mode of production and/or Feudalism, historical space relates to the ancient or classical mode of production (the polis or oligarchic slaveholding society), abstract space appears as the dominant space of Early Capitalism, contradictory space corresponds to the dominant space of Late Capitalism, and differential space is an imaginative proposition by Lefebvre that corresponds to collective and communal association of Communism where difference and lived experience are valued (Boer, 2015, p. 96). ${ }^{2}$

Another major constitutive element of Lefebvrean theory of space is the spatial triad framework, which also appears as the most popular element of the theory among the scholarship referring to the theory. With the triad, consisting of three interrelated elements, namely spatial practices, representations of space, and representational space, Lefebvre (1991) in his "unitary theory" of space aims to capture the physical, mental, and social "fields" of space (p. 11). At first, appearing as another unique proposition of Lefebvre, the triad, as
Harvey (2006, p. 279) notes, is not the original proposition of Lefebvre, but Lefebvre developed this framework by further expanding the propositions of Cassirer (1944), who considers human spatial experience consisting of tripartite sets of organic, perceptual, and symbolic spaces.

Thus, although the spatial triad framework appears as an important proposition of Lefebvre, as a conceptual framework, its full capacity can be grasped only when considered together with the periodization of space framework. Similarly, the periodization of space framework is not quite an authentic proposition, as it mostly corresponds to the dominant modes of production in human history accepted by Marxism. Thus, Lefebvre's theory appears to be an authentic theoretical construct, once the above-mentioned frameworks are considered together as a unity.

It is in the above-elaborated background that, in the existing large body of literature contextualizing the above-noted frameworks across various contexts, one sees that the spatial triad framework (or its various constituent elements) is the most frequently referenced Lefebvre's concepts; there is a frequent reduction of Lefebvre's theory into the spatial triad framework or selective adoption and appropriation of the various elements of the triad, while the periodization of space framework (or its various components) is not used frequently as a framework for analysis or is disregarded completely. And as argued above, Lefebvre's theory of the production of space appears as a unique framework only when both the periodization of space and the spatial triad components are considered as structurally interrelated units of the theory. Moreover, only when these two frameworks are considered together can we recognize Lefebvre's work as one of the most authentic and original contributions to the theory of space. Indeed, while the spatial triad or its various components are being considered detached from Lefebvre's general theory of the production of space, it could be argued that such applications have more of a descriptive functionality than a capacity for unveiling the underlying relationships and process pertinent to social space.

The context of Turkey is an interesting case for examining these propositions. A preliminary screening of the literature that applies and contextualizes the Lefebvrean conceptualizations on space in the Turkey context shows that although Lefebvrean conceptualizations on space have become popular in recent Turkey-related scholarship, it consists mostly of applications of the spatial triad framework or its various elements. Thus, this article presents a comprehensive survey of Lefebvre's theory of the production of space in the Turkish context, a survey of literature that "maps" the applications of Lefebvre's theorizations about space in the context of Turkey. The article below presents the logic, criteria, and steps of the survey conducted. In the discussion, the article summarizes general patterns and trends in the applications of Lefebvre's theory of the production of space to the Turkish context. 


\section{The Logic, Steps, and Criteria of the Survey}

To "map" applications of Lefebvre's theory of space in the Turkish context, several search criteria were set in advance. Since the aim was to "map" the state of the art in the contextualization of Lefebvre's theory of space within the Turkish context, several wide-scope keywords like Lefebvre, Turkey, and space were used for the preliminary literature search. ${ }^{3}$ Furthermore, to capture all relevant publications, English and Turkish language publications as well as "search in fulltext" options were employed. ${ }^{4}$ Since the selected keywords were wide in scope, the second stage of the search entailed evaluating titles, abstracts, and/or the full texts to further narrow the results to those that focus on the context of Turkey and involve the contextualization of various Lefebvrean concepts. Indeed, as noted above, since The Production of Space represents Lefebvre's most consistent elaboration of his production of space theory, and because it is also where he tried to present the most comprehensive conceptual framework underlying that theory, the basic criteria for the relevancy of any publication was whether it referred to this work. ${ }^{5}$

Many publications on urban studies with a focus on Turkey intensively mobilize the Lefebvrean concept of the right to the city and most of the research focuses first on this concept before discussing and contextualizing Lefebvre's theory on space or its constitutive elements. In this regard, although a more inclusionary survey of Lefebvrean propositions in Turkey-related academic publications bears important theoretical and practical implications, we excluded the mobilizations of this concept from our survey due to several key reasons. First of all, as we argued above, Lefebvre aims to present a "unitary theory" of space, and in this regard, in The Production of Space, one sees quite systematic and comprehensive conceptualizations and frameworks aimed at elaboration of such a theory. Those frameworks are the periodization of space frame and the spatial triad. While the notion of the right to the city was proposed by Lefebvre (1968) earlier than The Production of Space (Lefebvre, 1974), interestingly, in the later, there is no any referral to the notion of the right to the city. Thus, the right to the city, as a clear-cut concept, cannot be considered as a part of the theory of space. Hence, the mobilization of this concept in the context of Turkey was left out of the survey. Moreover, compared to other Lefebvrean notions, the notion of the right to the city bears a multitude of interpretations, and the analysis of works pertaining to its mobilization in Turkey-related scholarship requires another large-scale survey to trace its applications and interpretations. Besides, the concept of the right to the city goes beyond the status of being a scholarly notion and is rather a "proper and easily deployable" notion. Thus, to trace its mobilization in a particular context requires not only another large-scale survey but also another hypothesis and approach. Because, according to our hypothesis, Lefebvre's interrelated propositions on space (unitary theory on space) have been contextualized by the existing scholarship on Turkey rather fragmentary, and the aim of the current survey is to expose such fragmentary contextualization of the theory. Indeed, another survey aimed at "mapping" the contextualizations of the notion of the right to the city in Turkey-related scholarship, the struggles for the right to the city in Turkey and the role and motivations of various actors, particularly the role of researchers in knowledge production and dissemination, could provide important insights into theoretical and practical terms.

Since the survey aimed to reveal contextualizations of Lefebvrean concepts in the context of Turkey, another criterion for narrowing down the search results entailed focusing on the literature itself, which, instead of general references to Lefebvre's theory and related general propositions, tries to operationalize and apply Lefebvrean concepts. In other words, the main aim here was to eliminate those works that only elaborated propositions, such as "every society produces its own space" and "social space is a social product," and focus on works that were actual contextualizations of concepts and frameworks such as the spatial triad, periodization of space, or their various elements.

To "map" the state of the art of the Lefebvrean production of space framework in the context of Turkey, a final listed relevant literature (see Supplemental Appendix) ${ }^{6}$ was evaluated based on the following questions:

1. How is Lefebvre's theory of space being discussed in the study? What kind of readings of the theory (if any) exists in the study? Does the theory of space or its various concepts appear as the main framework for the study?

2. Which Lefebvrean framework or concepts are being applied in the study?

3. What are the geographical and historical scopes of the studies? Or of the cases on which these studies are focused? ${ }^{7}$

\section{Lefebvrean Concepts of Space in the Context of Turkey: General Trends and Patterns}

An analysis of 147 relevant studies showed that since 2000, there has been a steady increase in the number of works that apply various Lefebvrean concepts. Interestingly, after 2014, when The Production of Space appeared for the first time in Turkish translation (Lefebvre, 2014), the number of relevant works increased substantially (Figure 1). ${ }^{8}$

As the analysis shows, Lefebvrean conceptualizations on space have frequently focused on the Turkish context. In addition, these conceptualizations have been contextualized across a wide range of scholarship. Thus, the literature shows variations not only in terms of topics but also in terms of spatial and historical scope. Lefebvrean conceptualizations 


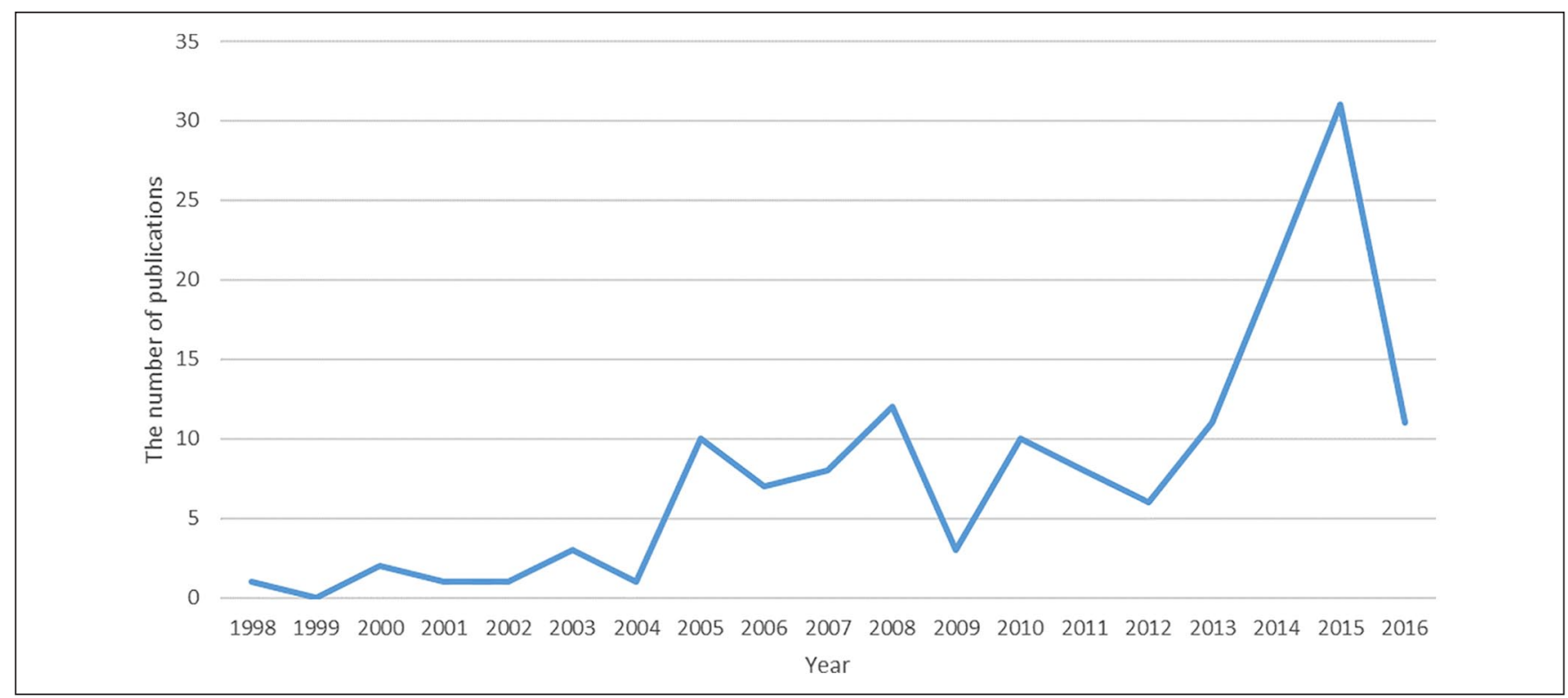

Figure I. Number of relevant publications by year.

have been contextualized in such research fields as literature (Kutlar, 2005; Mirze, 2005; Salman, 2015; Şişmanoğlu, 2003; Yeşil, 2016), communication (Demirkol, 2015), cinema (Aslan, 2014; Atabey, 2010; Ercan, 2011; Sar1, 2010; Uzunali, 2015), performance (Kılıç-Çalgıcı, 2013; Selen, 2010, 2012), and gender and queer studies (Pasin, 2014; Selen, 2010, 2012). However, the most frequent application of the Lefebvrean concepts is in the fields such as architecture and urban studies (Y. Baş, 2010; Çınar, 2014; Gegelioğlu \& Aydınlı, 2014; Karakaya, 2010; Kaypak, 2014a, 2014b; Koçak, 2008; Turhanoglu, 2010; C. S. Wilson, 2007) and urban social movements (Batuman, 2003; Erdi-Lelandais, 2013, 2014a, 2014b; Ergin, 2006, 2014; Firat, 2011); as these fields of research are traditionally more directly related to space as an "object" of inquiry, this pattern seems quite natural. Of particular note in a Turkish context was the application of Lefebvrean conceptualizations in numerous analyses of the 2013 Occupy Gezi Movement (Batuman, 2014, 2015a; Castagno, 2015; E. Erol, 2014; D. Erol, 2015; Eryılmaz, 2016; Hornstein, 2015; Işıklılar, 2016; Karasulu, 2014; Koyuncu, 2015; Şengül, 2015; Y1lmaz, 2015).

Another topic frequently elaborated in Lefebvrean concepts was the urban renewal projects and processes (Basa, 2015b; Baydar, Komesli, Yılmaz, \& Kılınç, 2016; Demirtaş-Milz \& Saraçoğlu, 2015; El-Kazaz, 2014; Eranıl, Tuna, \& Demirtaş-Milz, 2015; Önder, 2012; Penpecioglu, 2012) underway in Turkey since the early 2000s. Furthermore, a significant body of literature (At1c1, 2014; Casier, 2011; F. Gür, 2006; Pasin, 2009, 2014, 2016; Pekasil, 2016; Sarıtaş, 2007; Turan, 2011) was found to apply Lefebvrean frameworks while focusing on singular events, cases, buildings, and projects. Indeed, most of the works mentioned above, for example, works in literature studies and cinema studies, should also be considered as a part of this last group.

The focus of the existing studies presents an interesting pattern with respect to spatial scale and time frame. Regarding spatial scales, approximately $80 \%$ of studies focus on Istanbul, Ankara, and Izmir cities, thus replicating the general thrust of urban studies literature in Turkey, and its concern for major cities of Western portion of the country. Regarding the time frame of the studies, a significant portion of them emphasized the post-2000 period. However, another frequently analyzed period was the early Republican period in Turkey (1930-1940). The third historical period that was frequently analyzed was the period between 1960 and 1970 (Figure 2).

Arguably, as stipulated above, the Lefebvrean theory (of the production) of space in terms of structure consists of two main interrelated frameworks: (a) the periodization of space framework, consisting of consecutive periods of absolute, sacred, historical, abstract, and contradictory spaces, and (b) the spatial triad framework, consisting of spatial practices, representations of space, and representational space. When considered together, these two interrelated frameworks make the explanatory capacity of the Lefebvrean theory both powerful and unique.

When analyzing how those two frameworks and their various conceptual elements are being applied in the context of Turkey, several dominant trends and patterns in the contextualization of the theory could be discerned.

First, most of the relevant literature draws only upon the spatial triad of Lefebvre's framework (Ağlargöz, 2016; Altay, 2004; Basa, 2015a, 2016; Baydar et al., 2016; Ceylan, 2015; El-Kazaz, 2014; Eranıl et al., 2015; Ergin, 2006; Erkılıç \& Bayraktar, 2015; Gegelioğlu \& Aydınlı, 2014; 


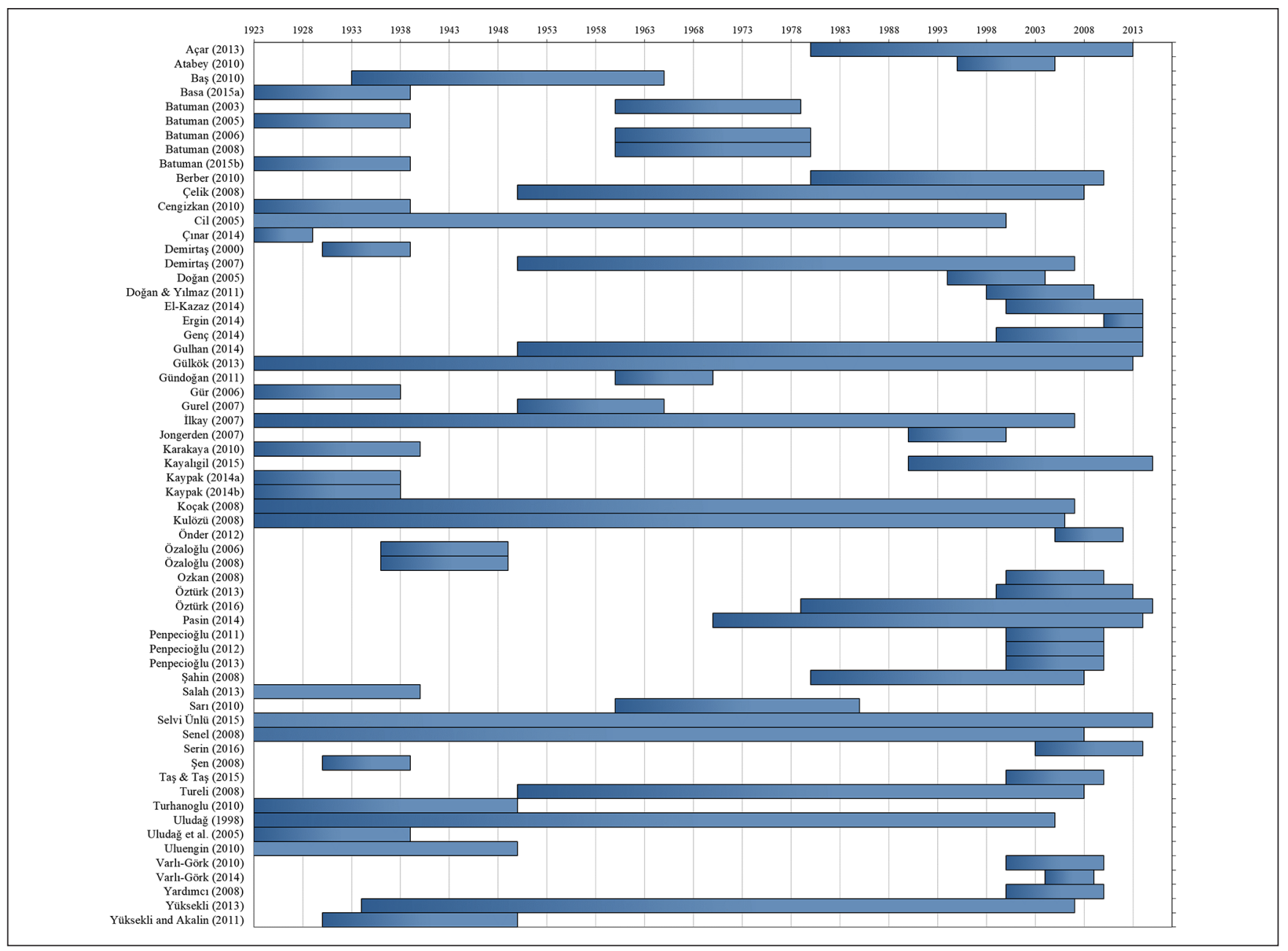

Figure 2. Historical scope of the contextualization of the theory.

Genç, 2014; Hornstein, 2015; İlkay, 2007; Kayalıgil, 2015; Khakee \& Grassini, 2015; Koyuncu, 2015; Kulözü, 2008; Önder, 2012; Salah, 2013; Sandıkc1, 2015; Turhanoglu, 2010; Y1lmaz, 2015; Yüksekli, 2013) or upon one or two elements of the spatial triad itself (Akaslan, 2006; Aslan, 2012, 2014; Ateş, 2015; Basa, 2015b; Batuman, 2014; Berber, 2010; F. A. Demirtaş, 2000; Gulhan, 2014; Jongerden, 2007; Kılıç-Çalgıcı, 2013; Mert, 2013; Mirze, 2005; Özgün, 2012; Pasin, 2013; Salman, 2015; Serin, 2016; Şişmanoğlu, 2003; Tirben, 2007; Turan, 2011; Z. S. Uludağ, 1998; C. S. Wilson, 2007; Yildiz, 2016). That said, in studies more generally, there is usually no contextualization or reference to Lefebvre's periodization of space framework. Due to the topics they tend to focus on, the periodization of space framework tends not to be a relevant framework for some studies. Interestingly, even studies that cover long historical periods, and where the periodization of space framework would have been a useful framework for analysis, it is still usually neglected. Instead, the analysis is conducted within the generally accepted periodization of Turkish political history.
Thus, analyses that refer to Lefebvre, instead of revealing the history of space, reveal the space of history, an issue pointed out several times by Lefebvre (1991) himself (pp. 46, 110111, 122).

Another dominant pattern relates to the nature of elaboration and contextualization of elements of the spatial triad. The spatial triad framework (along with its various elements) detached from Lefebvre's general theory of space, with each of the triad's elements also detached from the triad, results in convenient concepts for the analysis of various topics. ${ }^{9}$ According to Lefebvre (1991), representational space is the "space" of "some artists and perhaps of those, such as a few writers and philosophers" (p. 39); spatial practice "embraces production and reproduction, and the particular locations and spatial sets characteristic of each social formation" (p. 33), whereas the representation of space is defined as "conceptualized space, the space of scientists, planners, urbanists, technocratic subdividers and social engineers" (p. 38). Lefebvre's terse descriptions offer "convenient" definitions for analyzing say a literary work (i.e., a novel or poem) in terms of 
representational space, an architectural project in terms of the representation of space, or for using urban space or any particular set of locations in terms of spatial practices. It should be noted that in the context of Turkey, a majority of the relevant literature contextualizes Lefebvre's spatial triad and its various elements in this way. Thus, it could be argued that such an approach, if it only aims to analyze a literary work, or an architectural project, if it only facilitates the daily use of particular spatial sets, using Lefebvre's concepts, that are nonetheless detached from his general theory of (the production of) space, or employ elements of the triad independently of the triad itself, fits into Lefebvre's own critique. According to Lefebvre, intellectual labor under the present mode of production, such as material labor, is subjected to endless division. Consequently, space is continuously being fragmented, never able to unite, and as a result, "we are thus confronted by an indefinite multitude of spaces, each one piled upon, or perhaps contained within" (Lefebvre, 1991, p. 8). Another important argument against this kind of approach refers to the nature of Lefebvre's theory itself, a Marxist theory that places production and reproduction at its core. Thus, any conceptual element from such a theory, if detached from its actual context, runs a risk of becoming nothing more than a convenient metaphor, with only a descriptive function.

Finally, the last issue to be elaborated relates to whether elements of the spatial triad are worth using if they are detached from the theory or the triad itself. For example, with respect to the spatial practice element of the spatial triad, it seems that the field of geography, both in terms of conceptual apparatus and method, offers functional and productive frameworks for analyzing spatial practices. Toward this end, Hägerstraand's (1970) insights are an important example. Accordingly, if a study aims to elaborate an aspect of social space and fragments the integral nature of Lefebvre's theory by detaching its various concepts from the theory-a theory with an interrelated conceptual structure that appears as a unity - for the sake of such an inquiry, a search for "convenient" concepts could be conducted elsewhere.

Regarding the Lefebvrean periodization of space framework, the following general patterns could be discerned. First, there is frequent discussion related to various elements of this framework, first and foremost is the concern for notions of abstract and contradictory spaces, absent any mention however of the Lefebvrean history of space framework (i.e., this framework is not much discussed in the literature). Second, the notion of abstract space is sometimes reduced instead of the representation of space (conceived space). Although the abstract space of capitalism entails abstract representations of space, it is more accurate to consider the notion of abstract space as a period in the history of space and different from the abstract representation of space notion used by experts, planners, and technocrats. Third, in the Turkish context, the contextualization of the notion of abstract space acts principally as a kind of deus ex machina. According to Lefebvre, the production of space in capitalism is essentially a production of abstract space. As a result, within the relevant literature, to define the space in various contexts, there is a frequent use of this notion. However, how the production of this abstract space takes place, what aspects predetermine its "abstractness," and questions about "abstractness" itself and its corresponding characteristics are not very elaborated. Thus, the notion of abstract space serves as a "convenient" shorthand for researchers, a descriptive deus ex machina helping researchers to explain anything that concerns the production of space in capitalism.

One important aspect of the literature about Lefebvre's periodization of space framework refers not so much to its application but rather with how it was being read. In particular, this reading isolates a framework consisting of consecutive periods of production of absolute, abstract, and differential spaces, while notions of sacred, historical, and contradictory spaces are neglected. In Lefebvre's work, notions of sacred and historical spaces are not emphasized; furthermore, there are no separate chapters or subheadings for them such as those for absolute, abstract, and differential spaces. Consequently, more superficial readings tend to miss these notions. In addition, Lefebvre has elaborated complicated notions of abstract and contradictory spaces. Moreover, contradictory space could also be read as a particular period of abstract space associated with advanced capitalism. However, differentiating between these two concepts is important, as the space of industrial capitalism and that of advanced capitalism are quite different from one another.

That said, the existing literature contains applications of the Lefebvrean conceptualizations and frameworks, which, in their respective contexts, appear to be a relatively more systematic and comprehensive referral to the above-elaborated concepts and go beyond their fragmentary use. In other words, those works approach the respective theoretical frameworks in a more consistent way, especially to the spatial triad framework, without fragmenting its various elements for the sake of analysis. Among those works - indeed, one of the earlier works employing Lefebvrean spatial concepts and frameworks - is Ali Ekber Doğan's (2005) study focusing on the case of Kayseri city and analyzing Islamist municipalism and the production of space during 1994-2004. Other examples of such works include Neslihan Demirtaş's (2007) analysis of squatting (gecekondu) history in Turkey, focusing on the case of the Boğaziçi Neighborhood of Mamak District in Ankara; İlker Cörüt's (2015) ethnographic research on the assimilation strategies of the Justice and Development Party and the production of space in Hakkâri, focusing on the compulsory public service law for doctors; Seher Şen's (2008) study of modernization, informal practices, and urbanity in Ankara during the early Republican period; Feryal Aysin Koçak's (2008) study of the production of urban space in Ankara; Demirtaş-Milz and Saraçoğlu's (2015) study of the transformation of Kadifekale squatter settlements in Izmir, focusing on an urban renewal project; Çağrı Eryılmaz's (2016) study of the 2013 Gezi Movement, focusing on the production of 
space from below against the space produced by neoliberal policies; Nezihe Başak Ergin's (2014) study of post-2010 urban social movements, examining the ways of resistance, their associated patterns, and dynamics with respect to urban transformation projects in Istanbul; and finally, Işıl Gülkök's (2013) study of the production of sidewalks in Ankara between the period of 1923 and 2013. Indeed, most of these studies appear not only as systematic applications of the spatial triad framework and each of its constitutive elements but also in these works, one can see contextualizations of such Lefebvrean notions as the notions of abstract space (Cörüt, 2015; Demirtaş-Milz \& Saraçoğlu, 2015; N. Demirtaş, 2007; Ergin, 2014; Eryılmaz, 2016; Gülkök, 2013; Koçak, 2008; Şen, 2008), contradictory space (Doğan, 2005), or differential space (Eryılmaz, 2016). Finally, the body of writings by Bülent Batuman should also be mentioned. Batuman (2003, 2005, 2006, 2008, 2014, 2015a, 2015b), in his writings, offers interesting applications of various Lefebvrean concepts. Although Batuman's works are not a comprehensive and systematic application of Lefebvrean concepts, those works do reflect a productive and unique contextualization of the relevant theorizations in the Turkish context. ${ }^{10}$

\section{Conclusion}

As this survey has shown, Lefebvrean conceptualizations of space appear frequently in Turkey-related scholarship and as variously contextualized notions. Moreover, the applications of such concepts appear across a wide range of scholarship, such as literature, cinema, and gender and queer studies. However, the most frequent application of Lefebvrean concepts occurs in the fields such as architecture and urban studies and in urban social movements. An especially interesting finding was of the frequent application of Lefebvrean conceptualizations in an analysis of the 2013 Occupy Gezi Movement.

Existing studies demonstrate an interesting pattern with respect to spatial scale and time frame, such that approximately $80 \%$ of studies focus on various spatial scales of Istanbul, Ankara, and Izmir cities. This pattern replicates a feature characteristic of urban studies literature in Turkey, namely a focus on the largest cities of western Turkey: Istanbul, Ankara, and Izmir. Regarding the time frame focus of these studies, a significant portion of them concentrated on the post-2000 period. Another frequently analyzed period was the early period of the Turkish Republic (1930-1940). In terms of frequency, the third most popular historical period for analysis was the period between 1960 and 1970 .

According to the main assumption of the article, in The Production of Space (1991), the Lefebvrean production of space theory consists of two structurally interrelated main frameworks, namely, the periodization of space framework (consisting of absolute space, sacred space, historical space, abstract space, contradictory space, and differential space) and the spatial triad framework (consisting of spatial practices, representations of space, and representational space). Moreover, these two frameworks, when considered together, make the explanatory capacity of the Lefebvrean theory both more powerful and unique. In this regard, according to the survey, it appears that the spatial triad framework (and its various elements) is the most frequently referenced Lefebvrean conceptualization found in the Turkey-related literature, whereas the periodization of space framework (and its various components) is not being used frequently as a framework of analysis. Moreover, nearly all studies, even those which have a relatively longer historical scope, conduct their analysis within the generally accepted periodization of Turkish political history. Thus, analyses that refer the Lefebvrean framework, instead of focusing on the history of space, focus on the space of history.

Within the literature that refers to the periodization of space framework, or to notions of abstract and contradictory spaces, there is no reference to the Lefebvrean history of space framework, that is, this framework is not much discussed in the relevant literature. Moreover, the notion of abstract space is frequently reduced to the notion of a representation of space (conceived space), or it is used as a kind of deus ex machina, a convenient shorthand for the "explanation" of anything that concerns the production of space in capitalism.

Thus, in the case of recent Turkey-related scholarship, applications of Lefebvrean space theory are mostly fragmentary and related to partial readings of the theory and to applications of the theory's conceptual elements as convenient tools in an analysis rather than treating the theory with its concepts and frameworks as a structural unity. That said, within the literature, there are also interesting and productive applications of the Lefebvrean conceptualizations and frameworks to various spatial scales, and historical contexts and cases.

\section{Acknowledgments}

This article is based on the author's doctoral dissertation completed under the supervision of Prof. Dr. Tayfun Çınar in 2017 at the Graduate School of Social Sciences of Ankara University. However, some revisions were made and additional comments added to support the main arguments. The author would like to express his appreciation to Dr. Gülçin Erdi for her valuable comments and suggestions.

\section{Declaration of Conflicting Interests}

The author(s) declared no potential conflicts of interest with respect to the research, authorship, and/or publication of this article.

\section{Funding}

The author(s) received no financial support for the research, authorship, and/or publication of this article.

\section{ORCID iD}

Husik Ghulyan iD https://orcid.org/0000-0002-9292-1100 


\section{Supplemental Material}

Supplemental material for this article is available online.

\section{Notes}

1. For a detailed account on the timeline of Lefebvre's history of space, see Boer (2015), Grönlund (1993), and Shields (2005).

2. In a large body of literature, there are readings of several Lefebvrean notions, particularly that of abstract and contradictory spaces, that interpret the notion of abstract space as a space proper to capitalism including its advanced stage. At the same time, those works consider contradictory space as contradictions inherent to abstract space, that is, according to those interpretations, the notion of abstract space incorporates contradictory space per se (Fuchs, 2019; Leckie \& Given, 2010; Stewart, 1995; J. Wilson, 2013). Interestingly, our survey has shown the dominance of such readings and interpretations in Turkey-related scholarship. It is worthwhile to note the existence of contextualizations of the notion of the contradictory space in apparently non-capitalist contexts as well (Jackiewicz \& Bolster, 2003).

3. The search was conducted in EBSCOhost, ProQuest Dissertations \& Theses Global, Google Scholar, and National Thesis Database of the Turkish High Education Council databases. Thus, works that are not indexed by these databases have remained out of the search scope. Thus, this aspect should be considered as one of the limitations of the current survey.

4. In the first stage, by the application of the above-mentioned search keywords, 5,953 results from EBSCOhost, 3,008 results from ProQuest Dissertations \& Theses Global, and 6,833 results from Google Scholar were listed. Since the National Thesis Database of the Turkish High Education Council does not provide "search in full-text" option in its search platform, for this case, more detailed keywords were applied, such as Lefebvre, production of space, and abstract space, to search in title, abstract, and keyword sections of the database. As a result, 97 relevant dissertations were listed from this database. It is important to note that the search was conducted till the end of 2016, thus the end of 2016 appears as upper time scope of the survey. Furthermore, there is high possibility that some new relevant works dating before 2016 were indexed by those research databases after our search and were thus outside of our scope. For example, Google Scholar with its indexing algorithm continuously adds previously published papers appearing in the web in its database. Thus, there is the possibility that some relevant works, although having pre-2016 publication dates, remained outside of the survey's scope since they were indexed after our search.

5. For example, in several works, such as The Urban Revolution (Lefebvre, 2003) or Writings on Cities (Lefebvre, 1996), Lefebvre elaborates various conceptualizations directly or indirectly related to space, but those elaborations do not have a consistent nature.

6. The final body of literature, which has been considered as relevant for the survey, consists of 19 results from EBSCOhost, 19 results from ProQuest Dissertations \& Theses Global, 83 results from Google Scholar, and 26 results from National Thesis Database of Turkish High Education Council databases.

7. For the final lists of studies described and the detailed information of their topic, geographical and historical scope, and which conceptualizations of Lefebvre they apply, see the
Supplemental Appendix of this article.

8. In Turkey, within the context of popularization of Lefebvrean theorizations and propositions on cities and space, it is also worth noting the recent translations of Lefebvre's some other seminal writings, namely The Urban Revolution (2013), Right to the City (2016), and Rhythmanalysis: Space, Time and Everyday Life (2017) into Turkish.

9. Another dominant pattern of contextualization of spatial triad is the detachment of representation of space, representational space, and spatial practices from the triad itself. For example, while an urban park is under elaboration, it is analyzed as representational space, or while a monument is under elaboration, it is analyzed in terms of representation of space. But other aspects of the park or the monument, such as spatial practices, are not considered at all. These kinds of analyses are the perfect examples of negligence of the proposal of Lefebvre according to which the social space embodies these three aspects, no matter which aspect is more dominant at a particular case.

10. For a more comprehensive and fuller picture and the detailed information on the topic, geographical and historical scope, and which conceptualizations of Lefebvre these studies contextualize, see the Supplemental Appendix of this article.

\section{References}

*References present in supplemental appendix.

Açar, A. (2013). Küresel ve yerel akışlar kavşağında İstanbul'da mekanın yeniden üretimi: Gökdelenler örneğ $i$ [The reproduction of space in İstanbul in intersection of global and local flows: The skyscraper case] (Yayınlanmamış Doktora Tezi). Sosyal Bilimler Enstitüsü, Marmara Üniversitesi, İstanbul, Turkey.

Ağlargöz, O. (2016). "We are at this campus, there is nothing in this campus. . ": Socio-spatial analysis of a university campus. Tertiary Education and Management, 23(1), 69-83.

Akaslan, P. (2006). Etkinliğini Yitirmiş Kentsel Mekanların Kent Yaşamına Katılması [Regaining the urban places that have lost their effectiveness] (Yayınlanmamış Yüksek Lisans Tezi). Fen Bilimleri Enstitüsü, İstanbul Üniversitesi, Turkey.

*Akgün, B. (2001). Mekansal Imge-Mekansal Pratik İlişki/ İlişkisizliğinin Bursa'da 1950-1951 ve 1989 Bulgaristan Göçmenleri Üzerinde Incelenmesi [Research of spatial imagespatial practice related/unrelated on the immigrants of Bulgaria in 1950-1951 and 1989 in Bursa] (Yayınlanmamış Doktora Tezi). Fen Bilimleri Enstitüsü, Gazi Üniversitesi, Ankara, Turkey.

*Aksoy, E. S. (2015). Kent Ritmi ve Kamusal Alan İlişkilerinde Metro Istasyonlarl [The rhtym of city and public space with metro stations] (Yayınlanmamış Yüksek Lisans Tezi). Fen Bilimleri Enstitüsü, İstanbul Teknik Üniversitesi, Turkey.

Altay, D. (2004). Urban spaces re-defined in daily practices: The case of "Minibar," Ankara (Unpublished master's thesis). Graduate School of Natural and Applied Sciences, Middle East Technical University, Ankara, Turkey.

Aslan, P. Y. (2012). Söylem ve Deneyimde Kamusal Mekanın Dönüşümü: Bursa Kent Meydanı Örneği [The discorsive and experiential transformation of public space: the case of Bursa city square] (Yayınlanmamış Yüksek Lisans Tezi). Sosyal Bilimler Enstitüsü, İstanbul Üniversitesi, Turkey. 
Aslan, P. Y. (2014). "Aaahh Belinda” Filmini Lefebvre İle Okumak Nas1 Olurdu? [Reading the Film "Aaahh Belinda" with a Lefebvrian Perspective]. Posseible, 6, 8-19.

*Aslankan, A. (2014). Mixed-use high-rise [residential] complexes: A new urban form(ation) in Istanbul (Unpublished master's thesis). Graduate School of Natural and Applied Sciences, Middle East Technical University, Ankara, Turkey.

Atabey, M. (2010). Representing a (post-)modern city: The portrayal of Istanbul in recent Turkish films. In H. Zapf \& Ş. Toplu (Eds.), Redefining modernism and postmodernism (pp. 99-109). Newcastle upon Tyne, UK: Cambridge Scholars.

Ateş, B. (2015). A spatial impromptu: Green resistance by guerrilla gardening (Unpublished master's thesis). Graduate School of Natural and Applied Sciences, Middle East Technical University, Ankara, Turkey.

At1c1, M. (2014). The Construction of Public Realm in Contemporary Art: Reading on International Istanbul Biennial (Unpublished master's thesis), Graduate School of Science Engineering and Technology, Istanbul Technical University, Turkey.

*Baş, M. (2008). Reading Sulukule as a social production of space: Ownership/possession and boundaries of the dwelling (Unpublished master's thesis). Graduate School of Natural and Applied Sciences, Middle East Technical University, Ankara, Turkey.

Baş, Y. (2010). Production of urban form as the reproduction of property relations morphogenesis of Yenişehï-Ankara (Unpublished master's thesis). Graduate School of Natural and Applied Sciences, Middle East Technical University, Ankara, Turkey.

*Baş, Y. (2015). Bir (Kentsel) Ütopya Olarak "Ankara" Romanı. [The Novel Ankara as (Urban) Utopia]. ODTÜ Mimarlık Fakültesi Dergisi, 32(2), 79-98.

Basa, İ. (2015a). From praise to condemnation: Ottoman revivalism and the production of space in early republican Ankara. Journal of Urban History, 41(4), 711-738.

Basa, İ. (2015b). Kentsel Hafızanın Sürdürülebilirliği: Bir Mimarlık Stüdyosu Deneyimi [Sustainability of Urban Memory: An Architectural Studio Experience]. Sanat ve Tasartm, 15, 27-42.

*Basa, İ. (2016). Producing representational spaces for the Republican memory in Samsun, Turkey. Turkish Historical Review, 7(1), 1-32.

Batuman, B. (2003). Imagination as appropriation: Student riots and the (re)claiming of public space. Space and Culture, 6(3), 261-275.

Batuman, B. (2005). Identity, monumentality, security: Building a monument in early republican Ankara. Journal of Architectural Education, 59(1), 34-45.

Batuman, B. (2006). Spaces of counter-hegemony: Turkish architects and planners as political agents in the 1970s (Doctoral dissertation). State University of New York, Graduate School of Binghamton University. Available from ProQuest Dissertations and Theses Global.

Batuman, B. (2008). The image of urban politics: Turkish urban professionals and urban representation as a site of struggle. Journal of Architectural Education, 62(2), 54-65.

Batuman, B. (2014). Gezi'nin Söz Hali: Mekan, Temsil, Dil [The Word Case of Gezi: Space, Representation, Language]. Dosya 33: Kimlik ve Yer, 2014/1, 46-51.
Batuman, B. (2015a). "Everywhere is Taksim": The politics of public space from nation-building to neoliberal Islamism and beyond. Journal of Urban History, 41(5), 881-907.

Batuman, B. (2015b). Gazes in dispute: Visual representations of the built environment in Ankara postcards. The Journal of Architecture, 20(1), 21-46.

Baydar, G., Komesli, M., Yılmaz, A., \& Kılınç, K. (2016). Digitizing Lefebvre's spatial triad. Digital Scholarship in the Humanities, 33, 6-20. doi:10.1093/1lc/fqw061

Berber, Ö. (2010). Metropol Mimarlı ve Yerleşme Sorunu [Metropolis architecture and the problematic of placing] (Yayınlanmamış Doktora Tezi). İstanbul Teknik Üniversitesi Fen Bilimleri Enstitüsü, Turkey.

*Bernardoni, M. (2013). Graffiti: Spatial misuse and social production of urban space. In L. Borriello \& C. Ruggiero (Eds.), The unexpected impertinence of urban creativity (pp. 29-44). Salerno, Italy: Arti Grafiche Boccia.

Boer, R. (2015). Marxist criticism of the Hebrew Bible (2nd ed.). London, England: Bloomsbury.

Brenner, N., \& Elden, S. (2009). Henri Lefebvre on state, space, territory. International Political Sociology, 3(4), 353-377.

Casier, M. (2011). Beyond Kurdistan? The Mesopotamia Social Forum and the appropriation and re-imagination of Mesopotamia by the Kurdish movement. Journal of Balkan \& Near Eastern Studies, 13(4), 417-432.

Cassirer, E. (1944). An essay on man: An introduction to a philosophy of human culture. New Haven, CT: Yale University Press.

Castagno, C. A. (2015). Lightning in the night: Transgression in urban design (Doctoral dissertation). University of Washington. Available from ProQuest Dissertations and Theses Global.

Çelik, Ö. (2008). The pattern and process of urban social exclusion in Istanbul (Unpublished master's thesis). Graduate School of Social Sciences, Middle East Technical University, Ankara, Turkey.

Cengizkan, A. (2010). The production of a mise en scène for a nation and its subjects: Clemens Holzmeister et al. in the Ministries Quarter for Ankara, Turkey. The Journal of Architecture, 15(6), 731-770.

Ceylan, H. (2015). The impacts of post-disaster spatial structure on low income women: The case of Düzce (Unpublished master's thesis). Graduate School of Social Sciences, Middle East Technical University, Ankara, Turkey.

Cil, E. (2005). Exploring the construction of the identities of Kula, a place in Aegean Anatolia (Doctoral dissertation). The University of Michigan. Available from ProQuest Dissertations and Theses Global.

Çınar, Z. (2014). Beyond possibilities: Re-reading republican Ankara. International Journal of Social, Behavioral, Educational, Economic, Business and Industrial Engineering, 8(4), 11371142.

*Çolak, N. (2014). Kent Belleği Mekanlar: Ankara Pasajlart [Realms of city memory: The passages of Ankara] (Yayınlanmamış Yüksek Lisans Tezi). Sosyal Bilimler Enstitüsü, Başkent Üniversitesi, Ankara, Turkey.

*Çolpa, Z. M. (2015). Convivial urban spaces: The case of Sakarya street, Ankara (Unpublished master's thesis). Graduate School of Natural and Applied Sciences, Middle East Technical University, Ankara, Turkey. 
Cörüt, İ. (2015). An ethnographic account of compulsory public service by doctors in Hakkari: The limits of the AKP assimilation strategy and the production of space. In Z. Gambetti \& J. Jongerden (Eds.), The Kurdish issue in Turkey: A spatial perspective (pp. 105-135). New York, NY: Routledge.

*Demirel, S. (2005). "Production of space" in the post earthquake region: Three cases from Düzce (Unpublished master's thesis). Graduate School of Natural and Applied Sciences, Middle East Technical University, Ankara, Turkey.

Demirkol, G. (2015). Gündelik Hayat ve Basın: Girgır Mizah Dergisinde Gündelik Hayatın Dönüşümü, 1972 - 1989 [Everday life and press: The transformation of everyday life in Gırgır, 1972 - 1989] (Yayınlanmamış Doktora Tezi). Sosyal Bilimler Enstitüsü, Gazi Üniversitesi, Ankara, Turkey.

Demirtaş, F. A. (2000). Artificial nature: Water infrastructure and its experience as natural space (Unpublished doctoral dissertation). Department of Architecture, Massachusetts Institute of Technology, Cambridge.

Demirtaş, N. (2007). Critical moments of social spatialization in the neighborhood: An alternative reading of The mainstream gecekondu history (Unpublished master's thesis). The Institute of Economics and Social Sciences, Bilkent University, Ankara, Turkey.

Demirtaş-Milz, N., \& Saraçoğlu, C. (2015). Space, capitalism and Kurdish migrants in İzmir: An analysis of Kadifekale's transformation. In Z. Gambetti \& J. Jongerden (Eds.), The Kurdish issue in Turkey: A spatial perspective (pp. 185-212). New York, NY: Routledge.

Doğan, A. E. (2005). İslamct belediyelerin on yll (1994-2004). Kayseri örneğinde sosyo-mekansal bir çözümleme [Ten years of Islamist municipalities: A socio-spatial evaluation of the example of Kayseri] (Yayınlanmamış Doktora Tezi). Sosyal Bilimler Enstitüsü, Ankara Üniversitesi, Turkey.

Doğan, A. E., \& Yılmaz, B. (2011). Ethnicity, social tensions and production of space in forced migration neighbourhoods of mersin: Comparing the case of the Demirtaş neighbourhood with newly established ones. Journal of Balkan \& Near Eastern Studies, 13(4), 475-494.

Elden, S. (2001). Politics, philosophy, geography: Henri Lefebvre in recent Anglo-American scholarship. Antipode, 33(5), 809-825.

Elden, S. (2004). Understanding Henri Lefebvre: Theory and the possible. New York, NY: Continuum.

Elden, S., Lebas, E., \& Kofman, E. (Eds.). (2003). Henri Lefebvre: Key writings. New York, NY: Continuum.

El-Kazaz, S. (2014). Building politics: Urban transformation and governance in Cairo and Istanbul (Doctoral dissertation). Princeton University. Available from ProQuest Dissertations and Theses Global.

Eranıl, D. M., Tuna, U. Z., \& Demirtaş-Milz, N. (2015). A sociospatial analysis of urban transformation at a neighborhood scale: The case of the relocation of Kadifekale inhabitants to TOKİ Uzundere in İzmir. Cities, 48, 140-159.

Ercan, N. (2011). Türkiye Sinemasında Müphemleşen Mekân: A Ay ve Karanlık Sular [Ambivalence of space in Turkish Cinema: A ay and the Serpent's Tale] (Yayınlanmamış Yüksek Lisans Tezi). Sosyal Bilimler Enstitüsü, Ankara Üniversitesi, Turkey.

Erdi-Lelandais, G. (2013). Citizenship, minorities and the struggle for a right to the city. Citizenship Studies, 17, 817-836.
Erdi-Lelandais, G. (2014a). Right to the city as an urban Utopia? Practices of every day resistance in a Romani neighbourhood in Istanbul. In G. Erdi-Lelandais (Ed.), Understanding the city: Henri Lefebvre and urban studies (pp. 69-89). Cambridge, UK: Cambridge Scholars.

Erdi-Lelandais, G. (2014b). Space and identity in resistance against neoliberal urban planning in Turkey. International Journal of Urban and Regional Research, 38(5), 1785-1806.

Erdi-Lelandais, G. (Ed.). (2014c). Understanding the city: Henri Lefebvre and urban studies. Cambridge, UK: Cambridge Scholars

Ergin, N. B. (2006). Grassroots resistance against urban renewal: The case of Güzeltepe, Ístanbul (Unpublished master's thesis). Graduate School of Social Sciences, Middle East Technical University, Ankara, Turkey.

Ergin, N. B. (2014). An analysis of urban struggles in the process of practices of urban commoning: Resistance on "uncommon ground" "in, for and beyond" Istanbul (Unpublished master's thesis). Graduate School of Social Sciences, Middle East Technical University, Ankara, Turkey.

Erkılıç,H., \& Bayraktar,U.(2015). Resimlive TemsiliBir Triyalektik Mekân Okuması Olarak Ekümenopolis ["Ekümenopolis" as an Illustrated and Representative Trialectic Reading of Space]. Ileti-ş-im, 23, 113-134.

Erol, D. (2015). Kamusal Alanda Muhalif Beden [Dissenter body in public space] (Yayınlanmamış Yüksek Lisans Tezi). Fen Bilimleri Enstitüsü, İstanbul Teknik Üniversitesi, Turkey.

Erol, E. (2014). Re-territorialisation and the sites of autogestion within the periphery: Counter-hegemonic socio-spatial movements in Turkey. METU Studies in Development, 41(3), 465-481.

Eryılmaz, Ç. (2016). The spatial analysis of Gezi Movement in Turkey. Public Spaces: Times of Crisis and Change, 15, 191-219.

Firat, B. Ö. (2011). "Ve madem ki sokaklar kimsenin değil": Talan, dolandırıcılık ve hırsızlığa karşı kentsel müşterekler yaratmak" ["And since the streets belong to no one': Creating urban commons against plunder, robbery and theft]. Eğitim Bilim Toplum Dergisi, 9(36), 96-116.

Fuchs, C. (2019). Henri Lefebvre's theory of the production of space and the critical theory of communication. Communication Theory, 29(2), 129-150.

Gegelioğlu, A. F., \& Aydınlı, S. (2014). Mimarlık Üretimi Üzerine Bir İç Hesaplaşma: Tüketim Dinamiklerinin Uzantısında Mimari Bir Duruş [An internal account of architectural production: An architectural stance in the extension of consumption dynamics]. Tasarim + kuram, 10(17), 54-72.

Genç, F. (2014). Politics in concrete: Social production of space in Dïyarbakir, 1999-2014 (Unpublished master's thesis). Atatürk Institute for Modern Turkish History, Boğaziçi University, İstanbul.

Goonewardena, K., Kipfer, S., Milgrom, R., \& Schmid, C. (2008). Space, difference, everyday life: Reading Henri Lefebvre. New York, NY: Routledge.

Gottdiener, M. (1987). Space as a force of production: Contribution to the debate on realism, capitalism and space. International Journal of Urban and Regional Research, 11(3), 405-416.

Gottdiener, M. (1993). A Marx for our time: Henri Lefebvre and the Production of Space. Sociological Theory, 11(1), 129-134. 
Gregory, D. (1995). Lefebvre, Lacan and the production of space. In G. B. Benko \& U. Strohmayer (Eds.), Geography, history and social sciences (pp. 15-44). Amsterdam, The Netherlands: Kluwer Academic.

Grönlund, B. (1993). Lefebvre's ontological transformation(s) of space. Stockholm, Sweden: Nordplan.

Gulhan, S. T. (2014). The honorable exception: State and the social production of concrete space in Istanbul (Doctoral dissertation), State University of New York, The Graduate School of Binghamton University. Available from ProQuest Dissertations and Theses Global.

Gülkök, I. (2013). Production of sidewalks; the case of Ataturk Boulevard (Unpublished master's thesis). Graduate School of Natural and Applied Sciences, Middle East Technical University, Ankara, Turkey.

*Gültekin, A. A., \& Ünlü, A. (2015). Analysis of the environmental effects of gated communities on the neighborhood in the context of environmental stress. Megaron, 10(3), 343-354.

Gündoğan, A. Z. (2011). Space, state-making and contentious Kurdish politics in the East of Turkey: The case of Eastern meetings, 1967. Journal of Balkan \& Near Eastern Studies, 13(4), 389-416.

*Gür, B. F. (2002). Spatialisation of power/knowledge/discourse transformation of urban space through discursive representations in Sultanahmet, Istanbul. Space and Culture, 5(3), 237-252.

Gür, F. (2006). Sculpting Turkish nationalism: Atatürk monuments in early republican Turkey (Doctoral dissertation). Graduate School, The University of Texas at Austin. Available from ProQuest Dissertations and Theses Global.

Gurel, M. H. (2007). Domestic space, modernity, and identity: The apartment in mid-20th century Turkey (Doctoral dissertation). Graduate College, University of Illinois at Urbana-Champaign. Available from ProQuest Dissertations and Theses Global.

Hägerstraand, T. (1970). What about people in regional science? Papers in Regional Science Association, 24(1), 7-21.

Harvey, D. (2006). Space as a keyword. In D. Gregory \& N. Castree (Eds.), David Harvey: A critical reader (pp. 270-293). Oxford, UK: Blackwell.

Hornstein, N. (2015). Spatial perspectives of contention: Space, place, and policing in the 2013 Gezi Park protests (Unpublished Senior thesis). Faculty of the School of Arts and Sciences, Brandeis University, Waltham, MA.

İlkay, Y. (2007). The political struggle on and at public space: The case of Kizilay square (Unpublished master's thesis). Graduate School of Social Sciences, Middle East Technical University, Ankara, Turkey.

Işıklılar, D. (2016). Heterotopic practice of space: Taksim Gezi park revisited (Unpublished master's thesis). Graduate School of Natural and Applied Sciences, Middle East Technical University, Ankara, Turkey.

Jackiewicz, E. L., \& Bolster, T. (2003). The working world of the paladar: The production of contradictory space during Cuba's period of fragmentation. Professional Geographer, 55(3), 372382 .

Jongerden, J. (2007). The settlement issue in Turkey and the Kurds: An analysis of spatial policies, modernity and war. Leiden, The Netherlands: Brill.
*Jongerden, J. (2009). Yer Siyaseti: Türkiye Kürdistanı'nda Devlet ve Toplumun Mekânsal Düzenlenişi [Politics of place: The spatial organization of the state and society in Turkey's Kurdistan]. Toplum ve Kuram, (2), 213-230.

*Kahya, G. Y. (2015). Spatio-temporal structuration of art and cultural events mediated urban experience in Beyoğlu (Unpublished master's thesis). Graduate School of Natural and Applied Sciences, Middle East Technical University, Ankara, Turkey.

Karakaya, E. (2010). Construction of the republic in city space: From political ideal to planning principles (Unpublished master's thesis). Graduate School of Natural and Applied Sciences, Middle East Technical University, Ankara, Turkey.

Karasulu, A. (2014). "If a leaf falls, they blame the tree": Scattered notes on Gezi resistances, contention, and space. International Review of Sociology, 24(1), 164-175.

Kayaligil, P. K. (2015). Spaces of conflict: Memory, musealization and heterotopia in the city of Sivas, Turkey (Unpublished master's thesis). Graduate School of Social Sciences, Middle East Technical University, Ankara, Turkey.

Kaypak, Ş. (2014a). Atatürk'ün Kent Ve Kentleşmeye Bakışı; Ankara'nın Kentleşmesi [View of the city and urbanization of Atatürk; The case study: Urbanization of Ankara]. Mustafa Kemal Üniversitesi Sosyal Bilimler Enstitüsü Dergisi, 13(27), 349-365.

Kaypak, Ş. (2014b). Türk Aydınlanması'nın Kent ve Kentleşmeye Bakış1 [View of the city and urbanization of the Turkish enlightenment]. Akademik Sosyal Araştırmalar Dergisi, 2(1), 121-143.

*Kennedy, N. F. (2005). The ethos of architects towards an analysis of architectural practice in Turkey (Unpublished master's thesis). Graduate School of Social Sciences, Middle East Technical University, Ankara, Turkey.

Khakee, A., \& Grassini, L. (2015). Understanding multiple aspects of present space with the help of future scenarios: The case of Izmir, Turkey. Foresight, 17(6), 588-598.

Kılıç-Çalgıcı, P. (2013). Gündelik Hayatın Tiyatrosu: Alsancak’ta Teatral Etkinlikler [Theatre of Everyday Life: Theatrical Events in Alsancak]. Idealkent, 10, 256-271.

Kipfer, S. (2002). Urbanization, everyday life and the survival of capitalism: Lefebvre, Gramsci and the problematic of hegemony. Capitalism Nature Socialism, 13(2), 117-149.

Kipfer, S., Saberi, P., \& Wieditz, T. (2013). Henri Lefebvre: Debates and controversies. Progress in Human Geography, 37(1), 115-134.

Koçak, F. A. (2008). Social and spatial production of Atatürk Boulevard in Ankara (Unpublished master's thesis). Graduate School of Social Sciences, Middle East Technical University, Ankara, Turkey.

*Kor, B. (2013). Death, burial culture and spaces of memorialization: The case of Ankara Cebeci cemetery (Unpublished master's thesis). Graduate School of Natural and Applied Sciences, Middle East Technical University, Ankara, Turkey.

Koyuncu, B. (2015). Yeni Bir Kentsel Mekanın Göstergesi Olarak Taksim Gezi Park Eylemleri [As a sign of a new urban space: Taksim Gezi Park protests] (Yayınlanmamış Yüksek Lisans Tezi). Fen Bilimleri Enstitüsü, İstanbul Teknik Üniversitesi, Turkey.

Kulözü, N. (2008). Transformation of public space: The case of Hacibayram square (Unpublished master's thesis). Graduate 
School of Natural and Applied Sciences, Middle East Technical University, Ankara, Turkey.

*Kural, N. (2009). Parameters of sustainability in urban residential areas: A critique of Temelli/Ankara (Unpublished master's thesis). Graduate School of Natural and Applied Sciences, Middle East Technical University, Ankara, Turkey.

Kutlar, F. S. (2005). Sa'dâbâd Şiirlerinde Mekân [Place in Sa'dâbâd Poems]. İlmî Araştırmalar: Dil, Edebiyat, Tarih Incelemeleri, 19, 93-118.

Leckie, G. J., \& Given, L. M. (2010). Henri Lefebvre and spatial dialectic. In G. J. Leckie, L. M. Given, \& J. E. Buschman (Eds.), Critical theory for library and information science: Exploring the social from across the disciplines (pp. 221-235). Santa Barbara, CA: Libraries Unlimited.

Lefebvre, H. (1968). Le Droit à la Ville [Right to the city]. Paris, France: Anthropos.

Lefebvre, H. (1974). La Production de l'Espace [The production of space]. Paris, France: Éditions Anthropos.

Lefebvre, H. (1991). The production of space (D. Nicholson-Smith, Trans.). Cambridge, MA: Blackwell.

Lefebvre, H. (1996). Writings on cities (E. Kofman \& E. Lebas Eds., \& Trans.). Oxford, UK: Blackwell Publishers.

Lefebvre, H. (2003). The urban revolution (R. Bononno, Trans.). Minneapolis: The University of Minnesota Press.

Lefebvre, H. (2013). Kentsel Devrim [The urban revolution] [The urban revolution] (S. Sezer, Trans.) (1st ed.). İstanbul, Turkey: Sel Yayıncilik.

Lefebvre, H. (2014). Mekânın Üretimi [The production of space] (I. Ergüden, Trans.) (2nd ed.). İstanbul, Turkey: Sel Yayıncılık.

Lefebvre, H. (2016). Şehir Hakkı [Right to the city] (I. Ergüden, Trans.) (1st ed.). İstanbul, Turkey: Sel Yayıncilik.

Lefebvre, H. (2017). Ritimanaliz-Mekân, Zaman ve Gündelik Hayat [Rhythmanalysis: Space, Time and Everyday Life] (Batur, A. L. Trans.) (1st ed.). İstanbul, Turkey: Sel Yayıncılık.

Merrifield, A. (2013). Henri Lefebvre: A critical introduction. London, England: Taylor \& Francis.

Mert, C. (2013). Postyapısalcı Mekan Analizine Doğru: İstanbul, Kent ve Müzik [Towards a poststructuralist analysis of space: İstanbul, city and music] (Yayınlanmamış Doktora Tezi). Sosyal Bilimler Enstitüsü, Mimar Sinan Güzel Sanatlar Üniversitesi, İstanbul, Turkey.

Mirze, Z. E. (2005). Disorientation: "Home" in postcolonial literature (Doctoral dissertation). University of Nevada, Reno. Available from ProQuest Dissertations and Theses Global.

*Narkar, P. (2006). Urban [dis]order: Reinventing urban spaces, case of Istanbul, Turkey (Unpublished master's thesis). Division of Research and Advanced Studies, University of Cincinnati, $\mathrm{OH}$.

Önder, S. P. (2012). A tale of an uneven urban development: The socio-economic and socio-cultural contradictions of Tarlabasi Renewal Project (Unpublished master's thesis). Graduate School, Lund University, Sweden.

*Özaksoy, G. (2005). Urbanization and social thought in Turkey (Unpublished master's thesis). Graduate School of Social Sciences, Middle East Technical University, Ankara, Turkey.

Özaloğlu, S. (2006). Transformation of Ankara between 1935-1950 in relation with everyday life and lived spatiality (Unpublished master's thesis). Graduate School of Natural and Applied Sciences, Middle East Technical University, Ankara, Turkey.
Özaloğlu, S. (2008). The lived spatiality of Ankara (1935- 1950) through the memories of its citizens. In P. François, T. Syrjämaa, \& H. Terho (Eds.), Power and culture: New perspectives on spatiality in European history (pp. 19-43). Pisa, Italy: Plus-Pisa University Press.

Özgün, E. Ş. (2012). The sounds of political actions in the streets of Istanbul (Unpublished master's thesis). Graduate School of Arts and Social Sciences, Istanbul Technical University, Turkey.

Özkan, D. (2008). The misuse value of space: Spatial practices and the production of space in Istanbul (Doctoral dissertation). The College of Arts and Sciences, University of Rochester. Available from ProQuest Dissertations and Theses Global.

Öztürk, D. C. (2013). Socio-spatial practices of the pro-Kurdish municipalities: The case of Diyarbakir (Unpublished master's thesis). Graduate School of Social Sciences, Middle East Technical University, Ankara, Turkey.

Öztürk, M. (2016). Enformel Siyasi Ağların Gecekondu Üretim Biçimlerine Etkileri: Güzeltepe-Çayan Mahallesi Örneği [Informal political networks' impact on the production methods of squatter settlements: Case of Guzeltepe-Cayan Neighborhood] (Yayınlanmamış Yüksek Lisans Tezi). Fen Bilimleri Enstitüsü, İstanbul Bilgi Üniversitesi, Turkey.

Pasin, B. (2009). Dişil bir Temsili Mekân Olarak Türk Hamamı [The Turkish hammam as a feminine representational space]. In T. Balcığlu \& G. Baydar (Eds.), Tasarım tarihinin ötekileri (pp. 55-66). İzmir, Turkey: 4T Türkiye Tasarım Tarihi Topluluğu.

Pasin, B. (2013). Femaleness, femininity and feminotopia: The female hamam as a homosocial space. Kadin/Woman, 14(1), 55-77.

Pasin, B. (2014). A critical reading of the Ottoman-Turkish hamam as a queered space (Unpublished master's thesis). Graduate School of Natural and Applied Sciences, Middle East Technical University, Turkey.

Pasin, B. (2016). A critical reading of the Ottoman-Turkish hammam as a representational space of sexuality. METU Journal of the Faculty of Architecture, 33(2), 121-138.

Pekasil, T. (2016). Mardin Süryanilerinde Belleğin TeolojikKültürel Çerçevesi [Theological - Cultural Framework of Memory in Mardin Syriacs]. Tarih Kültür ve Sanat Araştırmaları Dergisi, 5(2), 26-58.

Penpecioğlu, M. (2011). Kapitalist Kentleşme Dinamiklerinin Türkiye'deki Son 10 Yılı: Yapılı Çevre Üretimi, Devlet ve Büyük Ölçekli Kentsel Projeler [The last decade of the capitalist urbanization dynamics in Turkey: The production of the built environment, state, and large-scale urban projects]. Birikim, 270, 62-73.

Penpecioglu, M. (2012). The political construction of urban development projects: The case of Izmir (Unpublished master's thesis). Graduate School of Social Sciences, Middle East Technical University, Ankara, Turkey.

Penpecioglu, M. (2013). Büyük Ölçekli Kentsel Projeler, Mekanın Üretimi ve Neo-liberal Hegemonya: İzmir Örneğinde Karşılaştırmalı Bir Araştırma [Large-Scale Urban Projects, Production of Space and Neo-liberal Hegemony: A Comparative Study of Izmir]. Megaron, 8(2), 97-114.

Şahin, Ö. (2008). Impacts of policies after 1980 on public buildings: The "unoccupied" buildings of Emlakbank, Sümerbank and TEKEL in Ulus in Ankara (Unpublished master's thesis). 
Graduate School of Natural and Applied Sciences, Middle East Technical University, Ankara, Turkey.

*Sakal, A. (2015). İstanbul Kentsel Mekanında Gündelik Taktikler [The daily tactics in Istanbul urbanspace] (Yayınlanmamış Yüksek Lisans Tezi). Fen Bilimleri Enstitüsü, İstanbul Teknik Üniversitesi, Turkey.

Salah, E. (2013). Sayfiye to banlieue: Suburban landscape around Anatolian railways, from mid-nineteenth century to the World War II (Unpublished master's thesis). Graduate School of Natural and Applied Sciences, Middle East Technical University, Ankara, Turkey.

Salman, C. (2015). Didem Madak Şiirinde Zaman ve Mekân [Time and Space in Didem Madak's Poems]. In E. Bora \& N. Zorlu (Eds.), Didem Madak'ı Okumak (pp. 217-250). İstanbul, Turkey: Metis Yayınları.

Sandikc1, Ö. (2015). Strolling Through Istanbul's Beyoğlu: In-Between Difference and Containment. Space and Culture, 18(2), 198-211.

Sar1, T. (2010). Türk Sinemasında Sosyal Yaşam Kurgusunun Mekan Kullanımına Yansiması [The reflection of social life to use of space in Turkish cinema] (Yayınlanmamış Yüksek Lisans Tezi). Fen Bilimleri Enstitüsü, İstanbul Teknik Üniversitesi, Turkey.

Sarıtaş, E. (2007). Video in the city possibilities for transformation in the urban space (Unpublished master's thesis). European Urban Cultures (POLIS), Brussels.

*Sarıyıldiz, H. Ö. (2007). Graffiti and urban space in Istanbul (Unpublished master's thesis). Graduate School of Social Sciences, Middle East Technical University, Ankara, Turkey.

Selen, E. (2010). The work of sacrifice: Gender performativity, modernity, and Islam in contemporary Turkish performance (1980s-2000s) (Doctoral dissertation). Department of Performance Studies, New York University. Available from ProQuest Dissertations and Theses Global.

Selen, E. (2012). The stage: A space for queer subjectification in contemporary Turkey. Gender, Place \& Culture, 19(6), 730-749.

Selvi Ünlü, T. (2015). Mersin'de İki Kamusal Mekân Üzerine Bir Mekân Kavramsallaştırması Denemesi [An attempt of conceptualization of space in the case of two public spaces in Mersin]. In Y. S. Levent \& M. Uçar (Eds.), Mersin'den Mimarlık Planlama Tasarım Yazıları (pp. 137-157). Mersin, Turkey: Mersin Üniversitesi yayınları.

Şen, S. (2008). The production of space and the construction of urbanity: Informal practices in 1930s Ankara (Unpublished master's thesis). Institute of Economic and Social Sciences, Bilkent University, Ankara, Turkey.

Senel, S. A. (2008). Unfixing place: A study of Istanbul through topographical practices (Doctoral dissertation). Department of Architecture, University College London. Available from ProQuest Dissertations and Theses Global.

Şengül, H. T. (2015). Gezi Başkaldırısı Ertesinde Kent Mekânı ve Siyasal Alanın Yeni Dinamikleri [Urban Space and Politics in the Wake of Gezi Uprising]. ODTÜ Mimarlık Fakültesi Dergisi, 31(1), 1-20.

*Şentürk, Y. (2014). Contradictory spaces of labor: The social and spatial practices of work life in Istanbul. In G. E. Lelandais (Ed.), Understanding the city: Henri Lefebvre and urban studies (pp. 189-211). Cambridge, UK: Cambridge Scholars.
Serin, B. (2016). The promised territories: The production of branded housing projects in contemporary turkey. European Journal of Turkish Studies, 23, 1-23. Retrieved from http://ejts. revues.org $/ 5383$

Shields, R. (2005). Lefebvre, love, and struggle: Spatial dialectics. London, England: Routledge.

Şişmanoğlu, Ş. (2003). Behçet Necatigil ve Şiirin Ev Hali [Behçet Necatigil and house of poetry] (Yayınlanmamış Yüksek Lisans Tezi). Ekonomi ve Sosyal Bilimler Enstitüsü, Bilkent Üniversitesi, Ankara, Turkey.

Soja, E. (1996). Thirdspace: Journeys to Los Angeles and other real-and-imagined places. Oxford, UK: Basil Blackwell.

Stanek, L. (2011). Henri Lefebvre on space: Architecture, urban research, and the production of theory. Minneapolis: University of Minnesota Press.

Stewart, L. (1995). Bodies, visions, and spatial politics: A review essay on Henri Lefebvre's the production of space. Environment and Planning D: Society and Space, 13(5), 609-618.

Taş, O., \& Taş, T. (2015). Ankara'da Sokak Sanatı: Kent Hakkı, Protesto ve Direniş [Street Art in Ankara: The Right to the City, Protest and Resistance Abstract]. Mülkiye Dergisi, 39(2), 85-114.

*Tataroğlu, E. G. (2006). Conceptual analysis of tourism: The case of Marmaris town in Turkey (Unpublished master's thesis). Graduate School of Social Sciences, Middle East Technical University, Ankara, Turkey.

Tirben, E. G. (2007). Lived space of white collar industrial employees: A case from Kocaeli (Unpublished master's thesis). Graduate School of Social Sciences, Middle East Technical University, Ankara, Turkey.

*Tunç, G. (2003). Transformation of public space: The case of Migros Akkopru shopping center (Unpublished master's thesis). Graduate School of Social Sciences, Middle East Technical University, Ankara, Turkey.

Turan, D. (2011). Mekan-Müzik Ilişsisi Açısından Türkiye'de "Taverna" ["Tavern" in Turkey in the context of the relationship between the space and music] (Yayınlanmamış Yüksek Lisans Tezi). Güzel Sanatlar Enstitüsü, Dokuz Eylül Üniversitesi, İzmir, Turkey.

Tureli, İ. A. (2008). Istanbul, open city: Exhibiting anxieties of urban modernity (Doctoral dissertation). Graduate Division, University of California, Berkeley. Available from ProQuest Dissertations and Theses Global.

Turhanoglu, F. A. K. (2010). Spatial production of Ankara as capital city of republican Turkey. International Journal of Interdisciplinary Social Sciences, 5, 309-318.

*Turkan, I. (2012). Alış-Veriş-Tüketim Mabetleri: Sosyoekonomik Açıdan Mekân Tüketiminde Türkiye Örneği [Özel Sayı] [The Temples of Shopping and Consumption]. Ileti-ş-im, 2, 85-104.

Uludağ, Z., Çağlar, N., \& Ulutav, Z. T. (2005). Conservation: Re-building an urban consciousness. Studies in the History of Gardens \& Designed Landscapes: An International Quarterly, 25, 23-39.

Uludağ, Z. S. (1998). The social construction of meaning in landscape architecture: A case study of Gençlik Parkı in Ankara (Unpublished master's thesis). Graduate School of Natural and Applied Sciences, Middle East Technical University, Ankara, Turkey. 
Uluengin, M. B. (2010). Secularizing Anatolia tick by tick: Clock towers in the ottoman empire and the Turkish republic. International Journal of Middle East Studies, 42, 17-36.

*Ustundag, Z. N. (2005). Belonging to the modern: Women's suffering and subjectivities in urban Turkey (Doctoral dissertation). Department of Sociology, Indiana University. Available from ProQuest Dissertations and Theses Global.

Uzunali, G. (2015). Zekï Demïrkubuz Sïnemasında Mekân Kullanımı [Use of space in Zeki Demirkubuz cinema] (Yayınlanmamış Yüksek Lisans Tezi). Sosyal Bilimler Enstitüsü, Hacettepe Üniversitesi, Ankara, Turkey.

Varl1-Görk, R. (2010). The making of a "city of culture": Restructuring Antalya (Unpublished master's thesis). Graduate School of Social Sciences, Middle East Technical University, Ankara, Turkey.

Varl1-Görk, R. (2014). The transformation of Antalya into a "city of culture": An attempt at rhythmanalysis. In G. Erdi-Lelandais (Ed.), Understanding the city: Henri Lefebvre and urban studies (pp. 139-168). Cambridge, UK: Cambridge Scholars.

Wilson, C. S. (2007). Remembering and forgetting in the funerary architecture of Mustafa Kemal Atatürk: The construction and maintenance of national memory (Unpublished master's thesis). Graduate School of Natural and Applied Sciences, Middle East Technical University, Ankara, Turkey.

Wilson, J. (2013). "The devastating conquest of the lived by the conceived": The concept of abstract space in the work of Henri Lefebvre. Space and Culture, 16, 364-380.

Yardımc1, S. (2008). Transformation of urban sphere: Hacıbayram square and its environment, Ankara (Unpublished master's thesis). Graduate School of Natural and Applied Sciences, Middle East Technical University, Ankara, Turkey.

*Yazıcı Yakın, A. (2015). Vilayetim Angara: Ankara Oyun Havaları ve Pavyon [My Hometown Angara: Traditional Ankara Dance Music and Night Club/Pavyon]. Kebikeç, 40, 37-62.
*Yelsalı Parmaksiz, P. M. (2014). From ars memoria to postmnemonic society: In search of lost times in Levent-Gültepe. Moment Journal, 1, 34-56.

Yeşil, S. Ş. (2016). Psikocoğrafya ve Bir Şehir Gezgininin Anıları [Psychogeography and the Memories of a City Traveller]. Monograf, 5, 124-149.

Yildiz, U. (2016). "Precarity" of the territorialized state: Immigrants re-drawing and re-mapping the borders. Journal of Borderlands Studies, 31, 521-536.

Y1lmaz, A. (2015). Gezï movement: An analysis in the context of place/space, the discursive practices and the society (Unpublished master's thesis). Graduate School of Natural and Applied Sciences, Middle East Technical University, Ankara, Turkey.

Yüksekli, B. A. (2013). Balıkesir Atatürk Parkı: Erken Cumhuriyetten Günümüze Türkiye'de Değişen Söylem ve Tasarımın Bir Kent Park Üzerinden Örneklenmesi [Balikesir Ataturk Park: An urban park as an example of changing discourse and design in Turkey from the early republican period to nowadays]. Uluslararası Sosyal Araştırmalar Dergisi, 6(25), 33-46.

Yüksekli, B. A., \& Akalin, A. (2011). Space as a projection of spatial practices: An urban park in Western Anatolia in the earlyrepublican period. Middle Eastern Studies, 47, 641-654.

Zieleniec, A. (2007). Space and social theory. London, England: Sage.

\section{Author Biography}

Husik Ghulyan holds a $\mathrm{PhD}$ degree in Urban and Environmental Studies (Ankara University, Turkey). He completed his undergraduate and graduate studies at the faculty of Geography, Yerevan State University (Armenia). His research interests cover political geography, urban studies, production of social space, and local and regional governance. 